も必多多なりとも鉛が含倠されてみるが、これる全く上記と同一理てよるものであつて青銅の湯

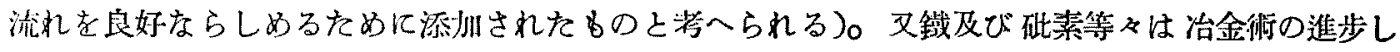

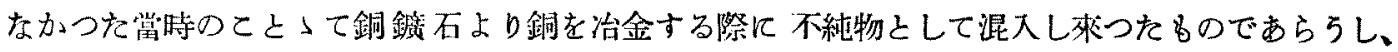

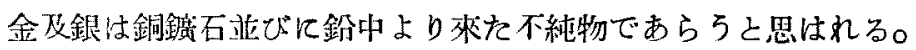

\title{
結
}

謇

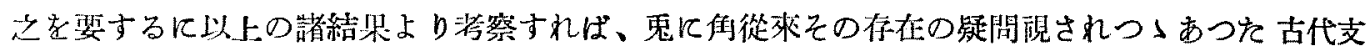
那に於ける純銅製品は實は存在してるた、換言すれば支那古代にあつてもェジプトその他の古代文

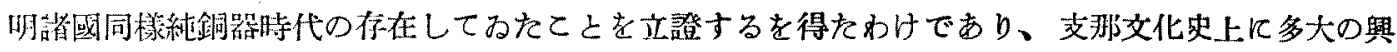
味ある新事望を提供するに至つた次第である。

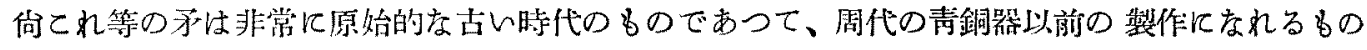
なること壮碓實であるが、份確かに殷代のものであつたとすれば文那に於ける純銅器使用の時代は 殷代頃であつた之云ひ得るのみならず、又次いで現はれた青銅器使用の勃興年代る亦殷代前後であ つたららと想像するてとも可能となつて椓る。

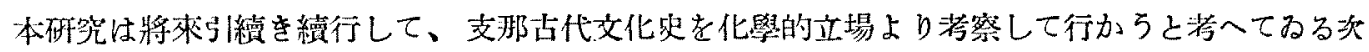
籍である。

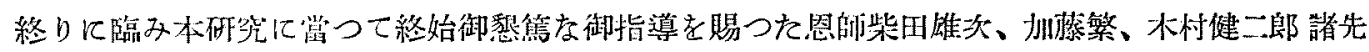

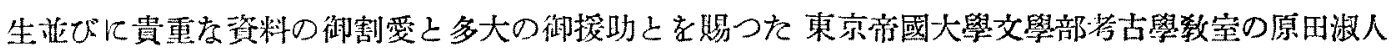
先生及び駒井和愛、汒上波夫网氏に深謝する、又金䐂組織學的研究方面に於いて 御便宜を與へられ

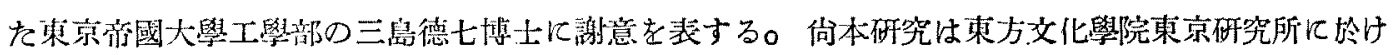
る硼究の一部である。

於東宗帝國大學理學部化學敎音

\section{東洋古代金屬器の化學的研究（第二報） 支那古代青銅器之部（その一）}

(昭租七㤰五月サ日受領 昭和七年七月廿五日卯刷)

緒道野鹤松

前解に於いて著者は河南省安陽縣殷墟より發掘された銅器乞外見上並びて製作技術等の全く酷似

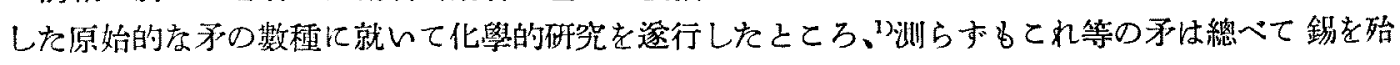
んど全く含有しない銅器で、從つて青銅器と稃すべをものではなく寧ろ純銅器と稱すべものであ

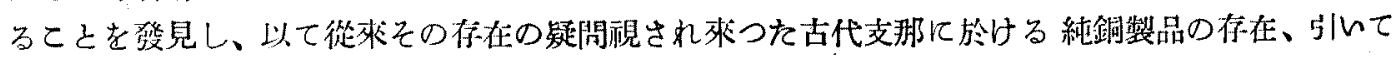
は純銅器時代の存在したととを確認するを得たのである。陉て著者は第一報に於いて述べたが如く 更に純銅器以外の青銅器、鐵器その他の金屬器に就いても利器を中心に於いて化學的研究を續行せ んとし、青銅利哭の數種に就いて研究を行つたからていに第二報として之を報告するとととする。

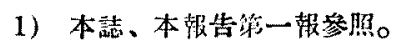


份本報告に先立ち婱に簡單に古代支那に於ける青銅器に對する知識の概略を記述するのも徒爾で

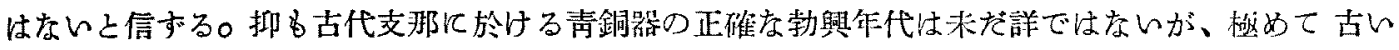

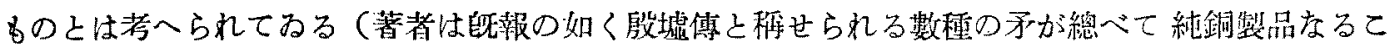
上を知り、古代支那に於いても青銅器時代以前に純銅器時代の存在してねたてとを確認寸るを得を のであるが、これ等の矛が事實所謂殷代のものであるとすれば古代支那に於ける青銅器時代の勃興

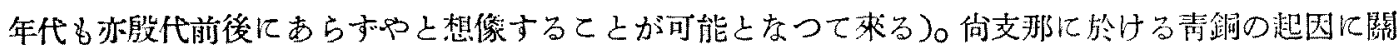

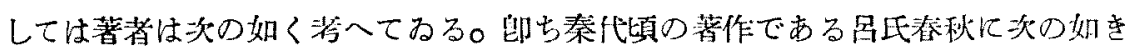

金柔䜻柔、合网乘則䉆剛。

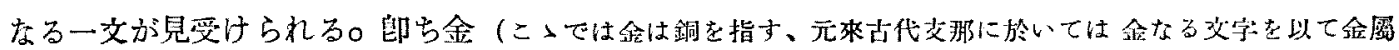
一般を表徽し月っ色に徒つて黄金、白金、赤金の所謂三品に分類し、次いで文黄金、白金、赤金、教余、玄金又

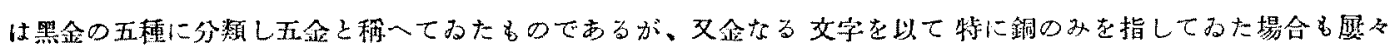

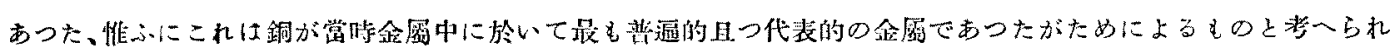

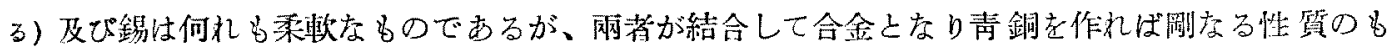

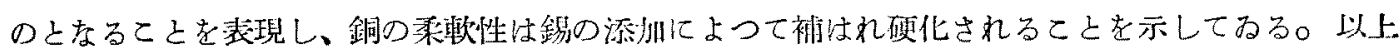

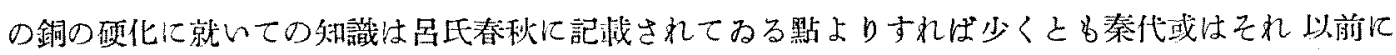
於いて无分儿會得されてみたるの之云ひ得る。然か子恐らくこの锡による铜の便化に就いての知識

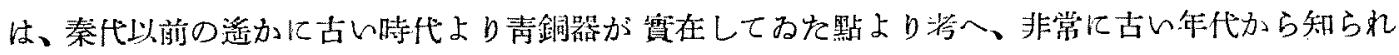

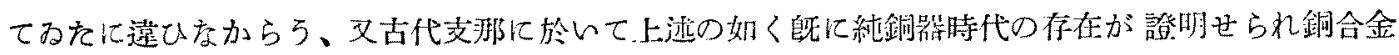
なる青銅器時代が直ちに之に追從して現はれ來つたと澕ふん゙き以上は、古代支那に於ける青銅器の 發端

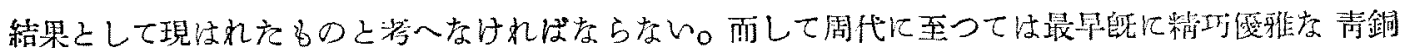

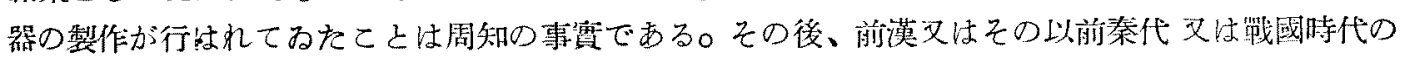

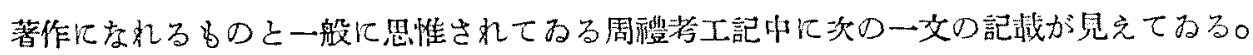

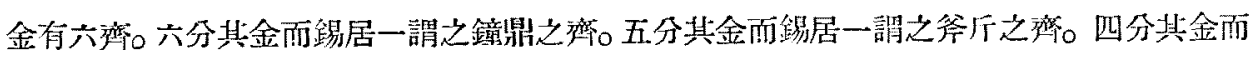

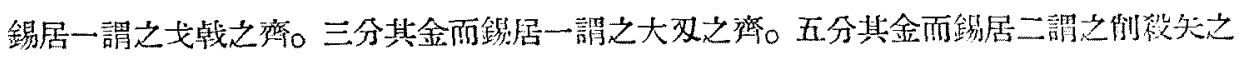

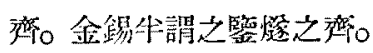

即ち周禮考工記の著作されれ年代に於いては既に青銅の利用方向に應して金（この金も銅老意味す

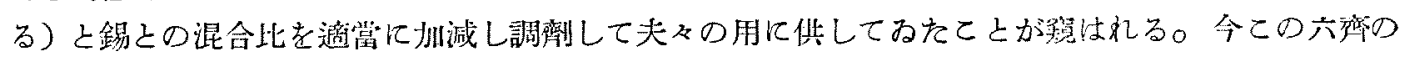
銅亡錫之の百分比算出して見ると次のやらであてるる。

\begin{tabular}{|c|c|c|c|c|c|c|}
\hline & 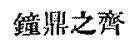 & 多原之蓶 & 戈戟之唯 & 大奴之辩 & 制溌知之率 & 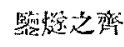 \\
\hline 銅 & 85.71 & 83.33 & 80.00 & 75.00 & 71.43 & 50.00 \\
\hline 糃 & 14.29 & 16.67 & 20.00 & 25.00 & 28.57 & 50.00 \\
\hline
\end{tabular}

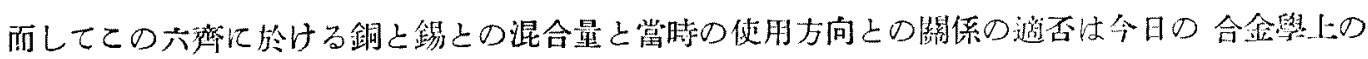
見地より見るとをは、二のものに就いて多少の改善を施すべを點あるも大體に於いて非常に裳を

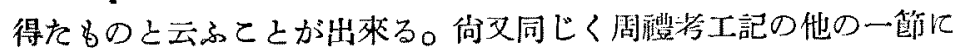

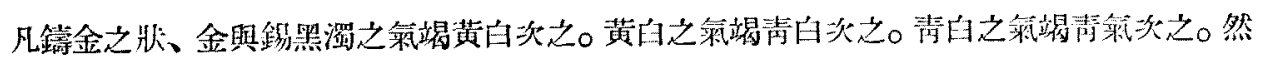
後可籍也。

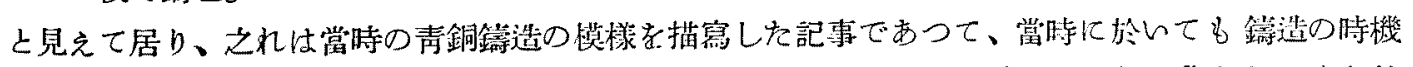

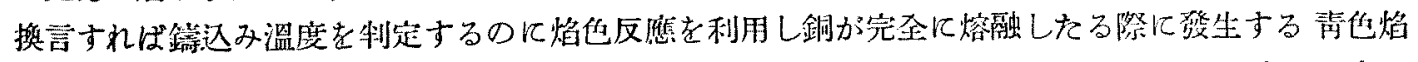

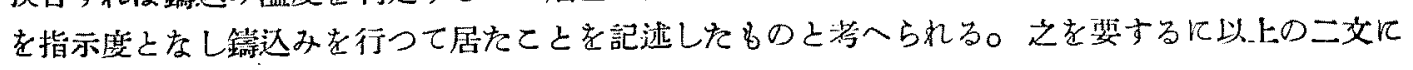


よつても周禮冷工記の著作された年代に於いては既に青銅關する知識は非常汇進步して居たてと を示してわる。佾古代支那て於いて鐵利器の出現したのは春秋末戰國時代の 頃よりであると溚へら れてるるが故汇戰國時代前後に於ける支那は所謂青銅器鐵器併用時代と云ふととになる。そして芰 那に於いて青銅器時代が国㛙の域に達したのは秦代前後であり、又その後前漢中栠以後になると青 銅利器は殆んぞ全くその影をひそめ純粹なる鐵器時代に入つたものとされてるる。然し考古學的に は利器に用ひを材料を標淮となし石器、銅器、青銅器、鐵器の各時代飞分類して居るがため、上記 の如く前漢中棐以後に至り全く純粹な鐵器時代が出現して來たのであるが、青銅器そのるの」利朋 がその後全く杜絕したものとは言ひ難い、郎ち利器以外の諧器具類の方面には依然として青銅器の

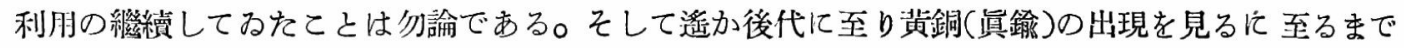
は銅合金としては等ら青銅の利汌が行はれてねたのである。

\section{實驗 之 部}

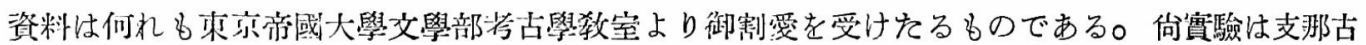

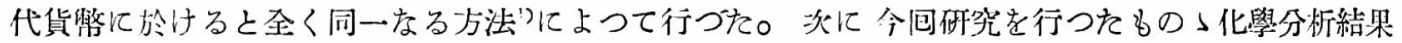
を示すことつする。

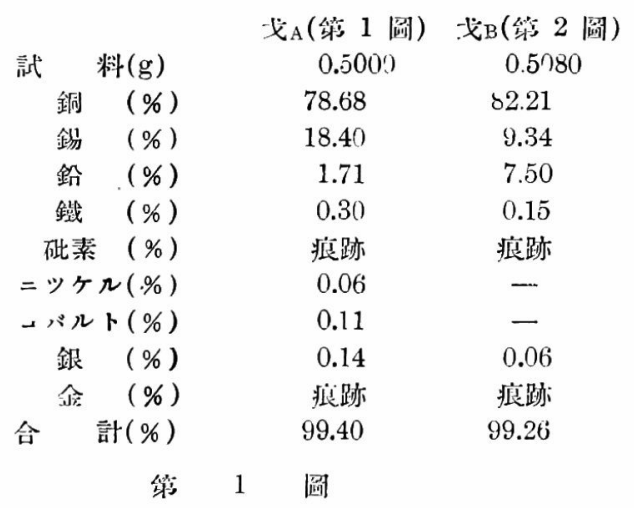
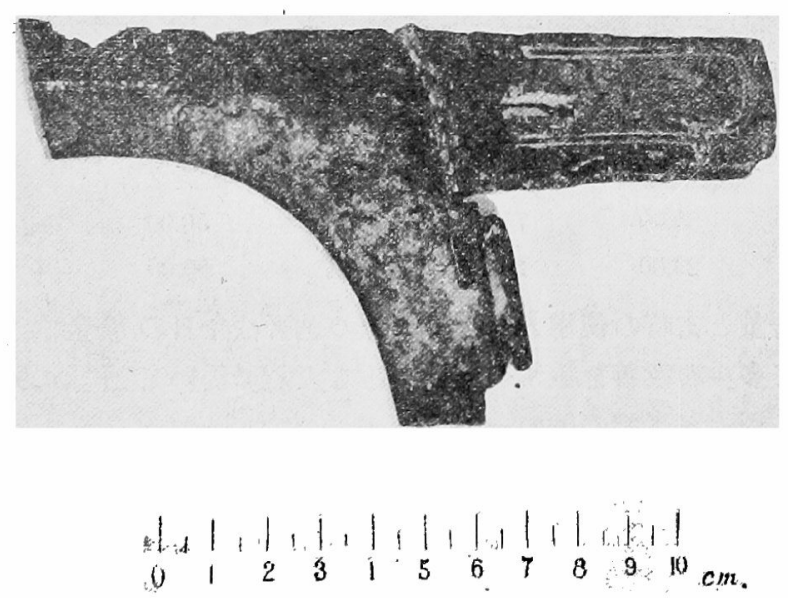

$\begin{array}{cc}\text { 斤A } \mathrm{A} \text { (第 } 3 \text { 圆 }) & \text { 斤 } \mathrm{B}(\text { 第 } 4 \text { 圖 }) \\ 0.5600 & 0.5070 \\ 68.65 & 82.18 \\ 9.70 & 12.24 \\ 19.83 & 2.60 \\ 0.08 & 0.08 \\ \text { 疷跡 } & \text { 痕跡 } \\ 0.04 & - \\ - & - \\ 0.03 & 0.03 \\ \text { 痕跡 } & \text { 痕跡 } \\ 98.33 & 97.13\end{array}$

次ぎに今包撮影したてれ等古青銓

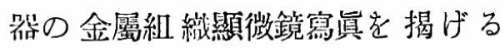
ことつする。第 5 嗞、第 7 浻、第

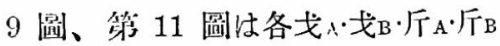
の表面を研腕したま〉の竄真で下 方の籍 6 圖、第 8 圖、第 10 圖、第 12 圖は同じく上方の表面をアムモ= ア水之過酸化水素水之の 混合液で床 㑁した寫黄である。佾何れも實物の 百倍涪大した竄真である。・

上記の化學分析並びに 金屬組織學 的結果より洘察すると、

戈:一寫道第 1 熰所载の戈A 的攻笢よりすれば、戈としては比洨

1) 本誌、 51 (1930), 463 . 本誌、 53 (1932), 100. 
進步した型でてれと全く同一な型のものに秦代の鉹の刻されたものを見受けるが做に、この型のも のは大體秦代前後の製作になれるるのと考へられる。而してこの戈を化學的研究の紹思より見る と銅 78.68\%. 錫 18.40\% であつて兩金屬のみの百分比は $8105: 18.95$ である、從つてての戈の組成は

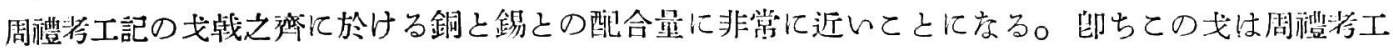
記(著作年代は詳でないが戰國時代义は前漢時代の著作になれるものと想像されてわる)の著作され

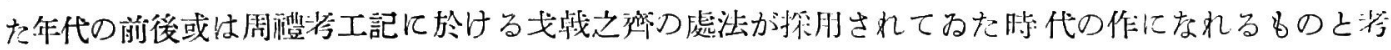

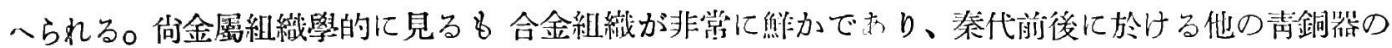

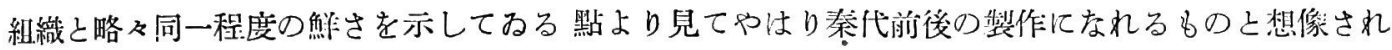

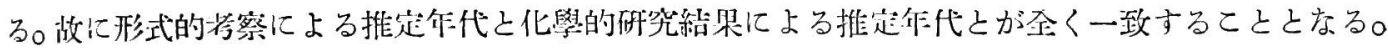

次を゙第 2 喟所成の戈 部類屬しずつと古い時代のものとされてねる。而して化學的研究の結果より見るもこのものは銅

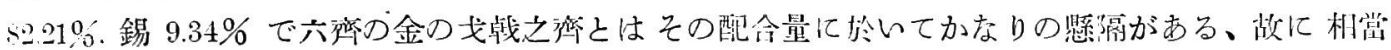
古い時代のものと想像さ れる。ての點に於いても 形式的考察と化學的研究 による考察とが略々一致 してわる。又金屬組織學 的にこの戈を見ると．上記 の吙く年代の古いと想像 される割合に相掌美しい 合金組織呈してるる、 これはこの戈の彆作され た年代に於いて子䥶造技 街はか索り進步して居つ たもの之将へられる。然 し戈、遙かに及ばない のは勿論のことである。 少戈には上記の二形式 以外に數 種の型のものが ある故將來 それ等の女の に就的同樣なる研究 を行はんと欲してるる。

斤: 一今回化學的研究 を行つを二種の厅は何 れも銅と錫との比が風䄈 荐工記の斧厅之唯に於け る銅と錫との配合量とは 相當な隔がある、又金 屬組織學的にこれ等を見 るも合金組織は 精吅なる

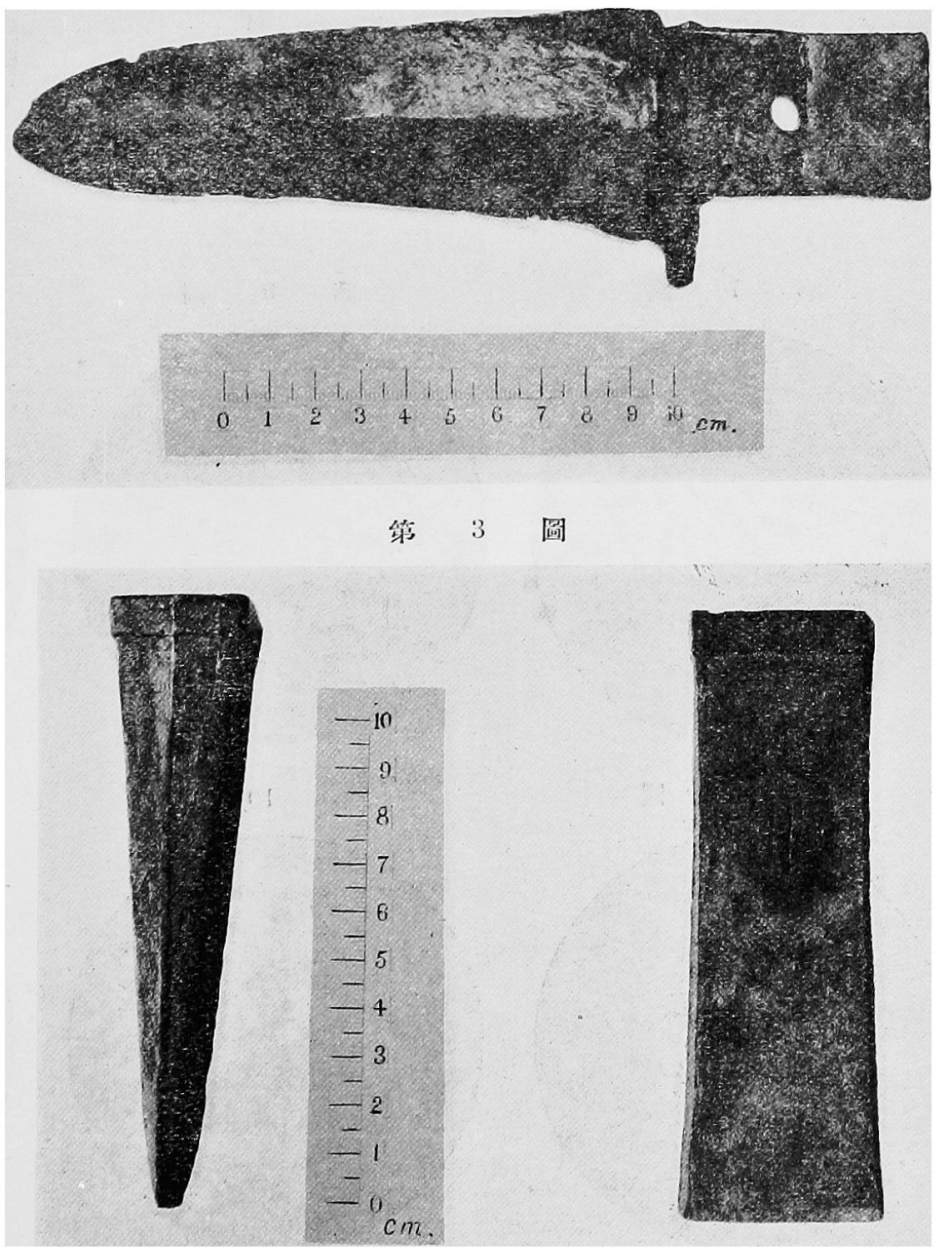


第 5 圆

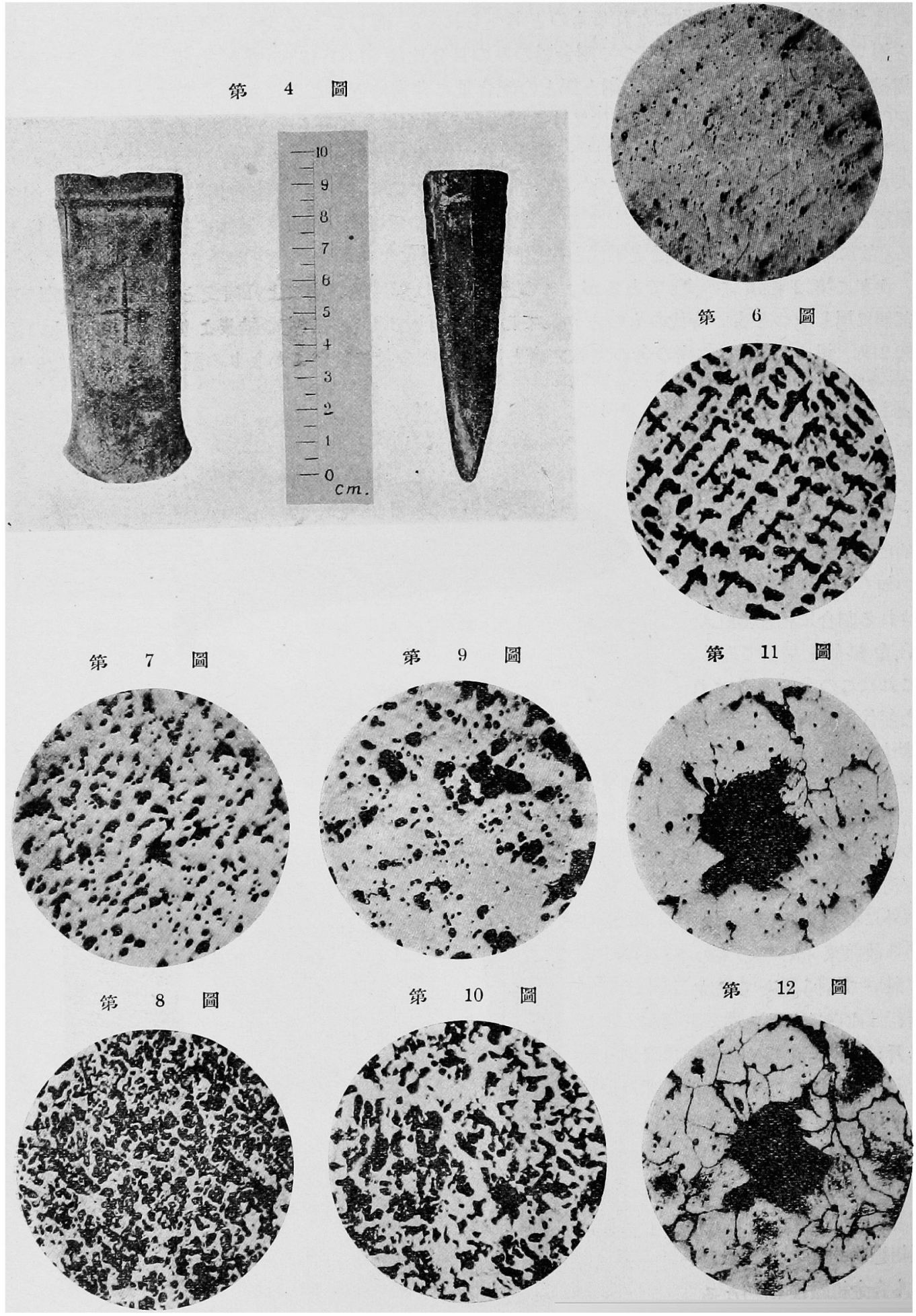




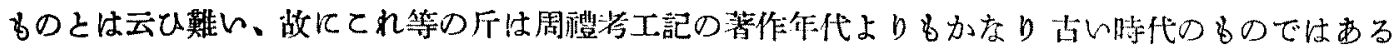
まいかと推測される。

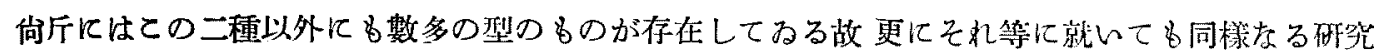
を行ひ 斤の㮔々な型の發生年代の新舊を化學的見地より考虑しゃうと思つてるる。

\section{結 言}

以上の如く戈二種、斤二種の化學的研究を行ひ、戈几關しては形式上よりする推定年代と化學的 見地よりする推定年代とが略々一致するてとが明らかとなつた。厅のちは未だ何れる形式的に發生 年代の順序が明らかにされてるないるのに就いて研觉索行つたので明碓なる判定を下し難いが、何 れも周禮考工記著作時代以前の㹈作几なるるのではあるまいかと洘入られる。少戈、斤何れの利器 にしても將來なほ多數の異れる型の資料に就いて化學分析並びに金屬組織學的研究を行ひ、その結

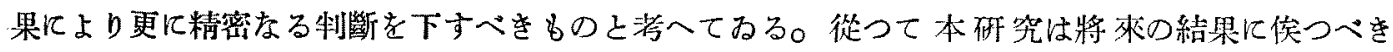
るの多々あるが故に今後とる繼續を重ねんとしてるる。

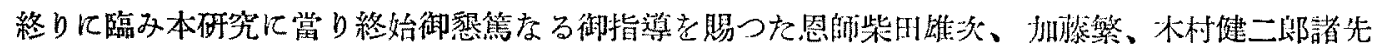

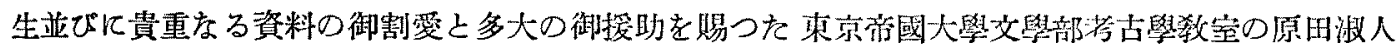
先生站びに駒井和愛、汇上波夫兩氏に深謝する、叉金屬組織學的研究方面に於いて 御便宜を與へら れた東京帝國大學工學部三島德七博士に謝意老表する。向本研究峙束方文化學院東京研究所几於け る研究の一部である。 